\title{
Under New Management: Equity Issues and the Attribution of Past Returns
}

\section{Citation}

Baker, Malcolm, and Yuhai Xuan. "Under New Management: Equity Issues and the Attribution of Past Returns." Journal of Financial Economics 121, no. 1 (July 2016): 68-78.

\section{Published Version}

http://www.sciencedirect.com/science/article/pii/S0304405X16300290

\section{Permanent link}

http://nrs.harvard.edu/urn-3:HUL.InstRepos:27336544

\section{Terms of Use}

This article was downloaded from Harvard University's DASH repository, and is made available under the terms and conditions applicable to Open Access Policy Articles, as set forth at http:// nrs.harvard.edu/urn-3:HUL.InstRepos:dash.current.terms-of-use\#OAP

\section{Share Your Story}

The Harvard community has made this article openly available.

Please share how this access benefits you. Submit a story.

\section{Accessibility}




\title{
Under New Management: Equity Issues and the Attribution of Past Returns*
}

\author{
Malcolm Baker \\ Harvard Business School and NBER \\ mbaker@hbs.edu \\ Yuhai Xuan \\ University of Illinois at Urbana-Champaign \\ yhxuan@illinois.edu
}

Journal of Financial Economics, forthcoming

\begin{abstract}
There is a strong link between measures of stock market performance and subsequent equity issues. We find that management turnover weakens the link between equity issues and the returns that preceded the new CEO. Moreover, there is a discontinuity in the distribution of equity issues around the specific share price that the CEO inherited, while there is no discontinuity around salient share prices prior to turnover. The evidence suggests that capital allocation involves an attribution of past returns not only to the firm but also to its CEO. A corollary is that a firm with poor stock market performance may be better able to raise new capital if its current CEO is replaced.
\end{abstract}

JEL classification: G32

Keywords: Equity issues; Seasoned equity offerings; Reference point; CEO turnover

\footnotetext{
* We thank an anonymous referee, Heitor Almeida, Lauren Cohen, Laura Liu, Ping Liu, Jeffrey Pontiff, Jay Ritter, Michael Roberts, Bill Schwert (the editor), Jeremy Stein, Avanidhar Subrahmanyam, Ryan Taliaferro, Jeff Wurgler, and seminar participants at Case Western Reserve University (Weatherhead), Chinese University of Hong Kong (Faculty of Business Administration), City University of Hong Kong (College of Business), University of Florida (Warrington), Harvard Business School, Hong Kong University of Science and Technology (Business School), Lingnan University (Department of Economics), Massachusetts Institute of Technology (Sloan), National University of Singapore (Business School), Singapore Management University (Business School), Tsinghua University (School of Economics and Management), the 2010 American Finance Association Annual Meetings, and the $11^{\text {th }}$ Annual Texas Finance Festival for helpful comments. The authors gratefully acknowledge financial support from the Division of Research of the Harvard Business School.
} 


\section{Introduction}

There is a strong and positive link between measures of stock market performance and equity issues. The neoclassical explanation for this pattern is that past returns reflect improved investment opportunities, which must in turn be financed. Another traditional explanation is that the cost of external equity is unusually low, either for rational reasons related to adverse selection or investor risk aversion or irrational reasons related to market-wide or firm-specific misvaluation. ${ }^{1}$ Putting these two together, firms with good performance require capital and have a lower cost of capital. Investors supply capital, believing that it will be put to good use. The identity of the management team does not figure prominently in either explanation. Whether the stock market performance came during the tenure of the current CEO is largely irrelevant.

In this paper, we ask whether equity issues are more sensitive to the value apparently created by the current CEO or the value inherited by the current CEO. ${ }^{2}$ Our results suggest that CEO-specific performance plays an important role in predicting which firms will raise equity capital. Equity issues are roughly twice as sensitive to what we label the CEO-specific portion of value creation as they are to inherited stock price performance. We decompose $Q$, which we define as the market-to-book assets ratio, into three parts: an initial level, the change prior to the arrival of the CEO, and the change since. The unconditional probability of an equity issue is 4.5 percent per quarter. A unit increase in the initial level of $Q$ or the change in $Q$ prior to the arrival of the CEO increases the probability of an equity issue by 2.0 to 3.2 percentage points, while a unit increase afterward increases the probability of an equity issue by almost twice as much, or 4.0 to 4.6 percentage points. These differences are large in comparison to the mean issuance level.

\footnotetext{
${ }^{1}$ For example, see Lucas and McDonald (1990) and Korajczyk, Lucas, and McDonald (1992) for an asymmetric information version of market timing, and Ritter (1991), Loughran and Ritter (1995), and Baker and Wurgler (2000) for an inefficient markets version.

${ }^{2}$ It is worth noting at the outset that we take a fairly expansive view of equity issues in most of our empirical tests, most notably including equity issued in the context of mergers and acquisitions. We also consider a narrower and binary notion of equity issues by examining follow-on equity offerings.
} 
While suggestive, these results have obvious limitations. Namely, we cannot distinguish CEO-specific value creation from merely recent value creation. For example, measurement error in our proxy for $Q$ might mean that recent first differences better define investment opportunities or asymmetric information than first differences in the more distant past. As a result, our preliminary test may have nothing to do with the attribution of performance to the current CEO.

To address this problem, we assign each firm in the non-turnover group a random turnover date. We then take a differences-in-differences approach, albeit not one where we have an instrument for CEO turnover, looking at how the difference between recent changes in $Q$ and more distant changes in $Q$ vary across the turnover and non-turnover groups. In both groups, the more recent change in $Q$ is more important for equity issuance, but the gap is larger when there is a turnover, increasing the probability of an equity issue by a further 1.3 to 1.7 percentage points.

While this suggests an attribution of past returns to the CEO, another explanation is that CEO turnover marks the sort of shift in firm strategy that breaks the link between past returns and equity issuance. Perhaps it is the underlying shift in strategy that causes the appointment of a new CEO and simultaneously the need for new capital, regardless of past performance. Capital is available to finance investment opportunities, but past returns are only an indicator of investment opportunity conditional on a strategic status quo. A related explanation is that a CEO transition puts all significant decisions on hold including raising new equity, while the new administration considers its options. This is effectively a transaction cost that delays the move toward neoclassical investment. The shift in personnel means that there is no need for new capital, again regardless of past performance. In both explanations, the identity of the CEO and the transition itself still matter, but for fundamental reasons.

We perform several additional tests to explore these alternative explanations. For example, we can quickly rule out the second alternative as the only explanation. Our main results do not come simply because the new CEO takes no immediate action in raising capital. The variance of equity issues is just as large after a CEO transition as in other periods. We can 
also rule out one version of the first alternative explanation. If the strategic shift involves improvements in investment opportunities, then debt issues and investment will behave like equity issues. Yet, we find no effect of CEO-specific returns on debt issues. And, we find no statistically significant results for the growth in long-term assets, capital expenditure, or profitability.

A broader interpretation is that the relevant opportunity is in restructuring liabilities, not increasing assets. CEO turnover typically coincides with poor performance. Equity issues in this context might be used to recapitalize a poorly performing firm after the arrival of a new CEO. Applying a double negative to our results, we might say that low, non-CEO-specific returns increase the probability of an equity issue.

However, we check whether our results come only from clear restructuring situations where the change in $Q$ prior to CEO turnover was negative. They do not. In fact, the sensitivity of equity issues to value created prior to the current CEO's tenure is similarly small when the changes in $Q$ are negative prior to the CEO's arrival as when the changes are positive; when the firm has or does not have leverage; when the turnover is forced or natural; or when the turnover involves an insider or outsider. We also find persistent effects even twelve or more months after turnover. In other words, distant past returns, which are arguably less important for immediate financing decisions, continue to have a differential effect.

Elaborate connections between CEO turnover and omitted firm characteristics are hard to cleanly rule out in a single test. But, in a third and final analysis to rule in the attribution story, we look for two types of discontinuity. These are cleaner, but less powerful, tests. Both the stock price at the arrival of the current CEO and the stock price of the prior stock offering if it is under the current CEO's control have a special effect on the decision to issue equity. There is a discontinuous jump in the distribution of follow-on offerings at these two stock prices. In contrast, the stock price of the prior stock offering, if it is not under the current CEO's control, generates no discontinuity. To the extent that past prices affect issuance, this process seems to start at the arrival of the CEO. The arrival price itself is discontinuously important, apparently 
generating a new reference point against which the CEO is judged. The price of the stock at the firm's last equity offering generally seems important in the decision to issue equity, in the sense that it generates a discontinuous jump in equity issues. And yet, this pattern is only visible if it occurs under the current CEO’s tenure.

Taken together, our results document a selective attribution of past returns to the CEO. These findings complement a growing literature that emphasizes the importance of the identity of top management in financial decision making, and the related phenomena of the "celebrity CEO” and the increasing CEO centrality in compensation. ${ }^{3}$ Our results could in principle reflect either the supply of or demand for capital. In other words, investors may provide capital conditional on CEO-specific returns. Alternatively, the CEO may be reluctant to raise capital at a price that is below the prevailing price at the start of his tenure. ${ }^{4}$ In this spirit, the paper complements the small but burgeoning literature on the importance of reference points in corporate finance. Loughran and Ritter (2002) and Ljungqvist and Wilhelm (2005) point to reference points and prospect theory as an explanation for IPO underpricing. Baker, Pan, and Wurgler (2012) study the effect of reference point prices on mergers and acquisitions. We present complementary evidence in the process of raising capital, where the real consequences are potentially significant.

\section{Equity issues and the attribution of past returns}

Mechanisms linking equity issues and valuation typically involve firm characteristics, like investment opportunities, asymmetric information, or misvaluation. In each case, valuation

\footnotetext{
${ }^{3}$ Bebchuk, Cremers, and Peyer (2011) measure CEO centrality as the "fraction of the top-five compensation captured by the CEO." Khuranna (2002) describes the executive search process and the focus on charisma in identifying CEO candidates. Malmendier and Tate (2009) investigate the impact of CEOs achieving "superstar" status on the performance of their firms.

${ }^{4}$ This idea is closely related to the disposition effect, or the tendency to sell winners and hold on to losing positions. Odean (1998) and Jin and Scherbina (2011), for example, find that individual investors and institutional investors are prone to disposition, despite the tax advantages of realizing losses. Shefrin and Statman (1985) attribute this to Kahneman and Tversky's (1979) prospect theory. Here, the CEO is reluctant to sell equity after it has declined in price.
} 
proxies for an underlying firm characteristic that is associated with the supply of or demand for new capital. Tobin (1969) and von Furstenberg (1977) focus on investment opportunities. High valuations, in this case, measure the marginal product of capital. Lucas and McDonald (1990) and Thakor and Whited (2011) focus instead on asymmetric information or gaps in beliefs. Changes in valuation, in this case, indicate periods of time when the gap between managers' and investors' knowledge or expectations is low, thus facilitating equity issues. Ritter (1991), Loughran and Ritter (1995), and Baker and Wurgler (2000) focus on market timing motives. High levels or changes in valuations, in this case, indicate periods where investors are willing to supply capital at low risk-adjusted cost.

In each, the object of empirical interest in the flow of capital is the firm, not the CEO running the firm. A potentially useful analogy is the literature on mutual funds. Sirri and Tufano (1998), Chevalier and Ellison (1999), and Berk and Green (2004) emphasize the flow of capital to funds that have produced high returns. To some extent, investors may be channeling flows to funds with high performance, and to some extent, they may be channeling flows to portfolio managers with high performance.

Applied to a corporate setting, this leads to a simple first prediction. The performance of the CEO, separate from the firm itself, influences equity issues. This is in some ways a more intuitive explanation for the link between changes in valuation and equity issues, for two reasons. First, the traditional explanations of investment opportunities, asymmetric information, and market timing make stronger predictions about the level of valuations and new capital than the change in valuation. Second, anecdotal evidence from the popular press and the structure of executive compensation and financial reporting suggest that the arrival price of the current CEO is an important benchmark.

Media accounts abound where the CEO-specific track record is documented as potentially relevant to investors. Examples of negative performance evaluation are commonplace: "The stock price [for Bombadier] is barely half of what it was when Tellier started on January 13, 2003” (Yakabuski, 2004); "Morgan Stanley shares closed Thursday at 
\$28.64, down about 37 percent since Mack took over in June 2005” (Connelly and Dani, 2009); "Ever since CEO Lee Scott took over the company in January 2000, however, Wal-Mart’s stock price has declined by about 30 per cent" (The Boston Globe, 2006); or "Coke shares are down $17 \%$ since the 62-year-old Mr. Isdell came out of retirement 18 months ago to spur a longoverdue turnaround in profit growth” (Terhune, 2005). Examples of positive performance evaluation are also easy to find: “Increasing your company's stock price by about 37 percent in one year tends to beget popularity, after all, and since Iger took over for Michael Eisner as leader of the Mouse House on October 1, 2005, he's become as lovable to investors as Disney characters are to their children... HAPPY ANNIVERSARY" (Lauria, 2006); or "During O'Reilly's 10-year reign as CEO, Chevron's stock price has gained about $60 \%$, with the company outperforming the S\&P 500” (Gelsi, 2009).

The structure of executive compensation also creates a reference point at the arrival of a new CEO. Options are typically struck at the money on the start date, and a disproportionate fraction of outstanding options come from the first contract. According to Standard and Poor's Executive Compensation (ExecuComp) database, over the period from 1990 through 2004, CEOs are granted an average of 278,360 option grants at a Black-Scholes value of $\$ 3.0$ million in the first year of their tenure. By contrast, in subsequent years, CEOs are granted an average of 167,860 option grants at a Black-Scholes value that is approximately 33\% lower at \$2.0 million. Relatedly, evidence from Murphy and Zimmerman (1993) and others suggests that financial reporting can be partially reset at the time of CEO turnover, because the new CEO uses the change in management as an opportunity to take a "big bath" from which future improvements will be easier to achieve.

Both the media accounts and the nature of option compensation point to an ancillary second prediction. The CEO arrival price is discontinuously important. This could in principle arise from either the supply of or the demand for capital. Media accounts point to the arrival price as a salient reference point in the minds of investors. Meanwhile, both the 
heightened attention of accepting a new job and the size of the initial option grant could equally well create a reference point in the mind of the new CEO.

Whether the effect of CEO-specific performance on equity issues reflects rational attribution will remain largely unanswered. On this question, there is an active debate in the mutual fund literature. On the one hand, the strong link between mutual fund flows and past returns appears despite no link between past and future returns, suggesting an irrational attribution of past returns. Frazzini and Lamont (2008) call this "dumb money," showing that flows actually predict negative returns at longer horizons. Likewise, a CEO-specific effect here may reflect a similar and excessive extrapolation of past returns or another well-documented bias, where subjects elevate the role of the individual relative to circumstance. ${ }^{5}$ On the other hand, Berk and Green (2004) emphasize a rational learning model where flows and decreasing returns to scale eliminate the link between past and future returns, despite the fact that past returns reveal stock-picking skills. The analogous neoclassical explanation for a CEO-specific effect here is that CEO-specific returns help to identify the marginal $Q$ of the firm. In this spirit, a growing literature emphasizes the importance of the $\mathrm{CEO}$ in firm decision making. ${ }^{6}$

We test these two predictions using data described below. The identification in the second prediction is cleaner, but less powerful. By contrast, the identification in the first prediction is more challenging, because the arrival of the CEO is not independent of firm characteristics. It may be these underlying firm characteristics that break the link between equity issues and past returns rather than a CEO-specific attribution process. We conduct several

\footnotetext{
${ }^{5}$ In controlled experiments, it is easier to identify attribution error. A classic study by Jones and Harris (1967) asked subjects to rate the political views of individuals who were chosen to read a passage either for or against Fidel Castro. Even when told that the assignment was random, subjects attributed some of the contents of the passage to readers' views, rating them as having a more positive or negative attitude toward Castro. This phenomenon, what Ross (1977) labeled the fundamental attribution error, suggests a somewhat different interpretation of the link between stock market performance and equity issues.

${ }^{6}$ For example, Bertrand and Schoar (2003), Graham and Narasimhan (2005), Xuan (2009), and Kaplan, Klebanov, and Sorensen (2012), among others, study how CEO characteristics and experiences influence aspects of corporate finance and performance.
} 
additional tests to rule out alternatives where the basic finding of a link between equity issues and CEO-specific past returns is endogenous.

\section{Data}

\subsection{CEO turnover}

Our sample starts with Standard and Poor's (S\&P) Executive Compensation (ExecuComp) database, which covers S\&P 1500 firms. We identify all CEO turnover events occurring between 1990 and 2011. For each turnover event, we verify or obtain the turnover date using Factiva news search and hand-collect the following additional information on the nature of turnover. A turnover is defined as internal if the CEO has been with the firm for more than one year at the date of the succession announcement. A turnover is considered forced if an announcement of forced resignation or firing of the departing CEO is reported in the news media, if the reason for departing is performance-related, or if the departing CEO is under the age of 60 without health problems or a position with another firm. We exclude those turnovers in which the new CEO stays in office for less than one year and those that involve the appointment of co-CEOs. ${ }^{7}$

\subsection{Equity issues, returns, and control variables}

We connect the ExecuComp data to the Compustat Industrial Quarterly files. For each firm-quarter, we gather a variety of financial data summarized in Table 1. The focus of the paper is equity issues. In addition to new equity finance, we collect data on the full range of financing and investing activities using flow of funds changes in the assets and liabilities of the quarterly balance sheet.

$$
\begin{aligned}
& \text { Cash }_{i t}+\text { WorkingCapital }_{i t}+\text { LongTermAssets }_{i t}= \\
& \text { Debt }_{i t}+\text { ExternalEquity }_{i t}+\text { RetainedEarnings }_{i t}+\text { OtherLiabilities }_{i t}
\end{aligned}
$$

\footnotetext{
${ }^{7}$ Further details on the CEO turnover data are described in the Internet Appendix and tabulated in Appendix Table A1.
} 
Starting with the assets side of the balance sheet, Cash is cash and short-term investments (Compustat Quarterly Item 36). WorkingCapital is current assets (Item 40) minus current liabilities (Item 49) plus debt in current liabilities (Item 45) minus cash. LongTermAssets is assets minus current assets. We can decompose total assets on the liabilities side of the balance sheet as well. Debt is defined as the sum of long-term debt (Item 51) and debt in current liabilities. ExternalEquity is defined as book equity minus balance sheet RetainedEarnings (Item 58). Book equity is defined as total assets less total liabilities (Item 54) and preferred stock (par value, Item 55) plus deferred taxes (Item 52). This leaves some other long-term liabilities, including minority interests, and so on, which we define as a residual OtherLiabilities. We compute changes in these quarterly balance sheet measures and scale by total assets. We also note when the change in ExternalEquity exceeds 5\% of assets. This occurs in 4.55 percent of the sample of firms where no CEO turnover occurred and 4.35 percent of the sample where a CEO turnover has occurred within the last three years.

\section{[INSERT TABLE 1 HERE]}

Finally, we control for assets, $Q$, leverage, and profitability. Total assets $A$ is Compustat Quarterly Item 44. $Q$ is defined as the ratio total of assets minus book equity plus market equity (Item 14* Item 61) all over total assets. Leverage D/A is defined as debt divided by total assets. As before, debt is defined as the sum of long-term debt and debt in current liabilities. Profitability EBITDA/A is defined as operating income before depreciation (Item 21) divided by total assets.

We require complete data on each of the financing and investing activities, past returns for three years, and the four control variables. This leaves us with a sample of 87,488 firmquarters between 1990 and 2005. Of those, 29,663 firm-quarters involve a firm that has experienced a CEO turnover within the last three years. In the remaining 57,825 firm-quarters, the active CEO has been at the helm for at least three years. Table 1 compares these groups.

There are a few clear patterns in the summary statistics. First, the turnover firm-quarters are different from the no turnover sample. They are somewhat less profitable, with less asset 
growth of all types. The bulk of the lower asset growth comes from lower retained earnings. This is coming in part from write-downs, as operating profitability is lower, but by a more modest amount. The bottom line is that these firms are facing more than an exogenous change in the CEO, so we will need to keep this in mind, adding control variables to the regression specification and taking care in the interpretation of the results.

\section{CEO-specific $Q$, past returns, and equity issuance}

Past stock market performance is correlated with a number of corporate financing decisions. Equity issues and investment follow high past returns; and, repurchases follow low past returns. Typically, past returns are interpreted as a characteristic of the firm - indicating investment opportunities, asymmetric information, or misvaluation - not the particular management team running the firm. For example, Lucas and McDonald (1990) and Korajczyk, Lucas, and McDonald (1992) consider the role of asymmetric information in linking past returns and equity issues, while Stigler (1964), Ritter (1991), Loughran and Ritter (1995), and Baker and Wurgler (2000, 2002) consider the role of misvaluation. ${ }^{8}$

Our goal is to separate out the effect of firm returns from CEO returns. A challenge is that the value changes under the current CEO are by definition more recent than the value changes prior to turnover. Because we do not have an instrument for CEO turnover, we assign each firm in the non-turnover group a random turnover date. ${ }^{9}$ We select this by drawing a turnover lag at random using the dates from our turnover sample, matched by 2-digit SIC industry and year-quarter. This methodology ensures that the distributions of lags are similar for the turnover and the non-turnover groups. ${ }^{10}$ We then run regressions of the following type:

\footnotetext{
${ }^{8}$ These patterns also appear in our sample. To save space, these are available in the Internet Appendix in Tables A2 and A3.

${ }^{9}$ There are only 12 CEO deaths in our sample period, and we do not find statistically significant results using this small sample.

${ }^{10}$ We are able to assign a turnover date to $94 \%$ of the observations in the non-turnover group using this methodology.
} 


$$
\begin{aligned}
\text { EquityIssuance }_{i t}= & a_{t}+\left(b_{1}+b_{2} \text { Turn }\right)\left(Q_{i, t-1}-Q_{i, C E O}\right)+\left(c_{1}+c_{2} \text { Turn }\right)\left(Q_{i, C E O}-Q_{i, t-13}\right) \\
& +\left(d_{1}+d_{2} \text { Turn }\right) Q_{i, t-13}+\text { eTurn }+f X_{i, t-1}+u_{i t}
\end{aligned}
$$

where Turn is equal to one if the firm is in the turnover group. The difference, $b_{2}-c_{2}$, captures how the effect of recent changes in $Q$ on equity issuance, compared to the effect of more distant changes in $Q$, differs across the turnover and the non-turnover groups.

This estimation is presented in Table 2. The difference, $b_{2}-c_{2}$, is positive across all specifications, using either net equity issues as a percentage of assets or an indicator variable as the dependent variable. While the recent change in $Q$ is more important for equity issuance than the more distant change in $Q$ for both the turnover and the non-turnover groups, the gap is significantly larger when there is an actual turnover, increasing the probability of an equity issue by a further 1.25 to 1.69 percentage points per quarter. Using the non-turnover group to control for the effect of recency of the changes in $Q$, we find that changes in $Q$ under the control of the current CEO still have a significantly stronger impact on issuing activity than the changes prior to arrival.

\section{[INSERT TABLE 2 HERE]}

To show this result another way, we estimate the following equation within the subsample of observations in the non-turnover group, repeating the process 500 times with 500 different sets of randomly assigned turnover dates: ${ }^{11}$

EquityIssuance $_{i t}=a_{t}+b\left(Q_{i, t-1}-Q_{i, C E O}\right)+c\left(Q_{i, C E O}-Q_{i, t-13}\right)+d Q_{i, t-13}+e X_{i, t-1}+u_{i t}$.

Instead of using a single set of randomly assigned turnover dates in a nested test, as in equation (2), this test does not rely on a matching procedure. Instead, we plot the full distribution of the estimated difference $b-c$ for the non-turnover group in Figure 1, against the equivalent estimate $b-c$ of for the turnover group (0.29). ${ }^{12}$ The simple question is whether the

\footnotetext{
${ }^{11}$ We thank Michael Roberts for this suggestion.

12 The estimation results of Equation (3) for the turnover group are presented in Appendix Table A4 in the Internet Appendix.
} 
estimates of $b-c$ for the turnover group fall within this distribution, or, in other words, would we have expected, given the effect of recent returns, to find these results by chance.

\section{[INSERT FIGURE 1 HERE]}

We use levels of equity issues as the dependent variable and include controls for lagged profitability, size, and leverage. ${ }^{13}$ We also control for year-month and firm fixed effects. We use random assignment by industry and year-quarter, and by year-quarter alone in an attempt to generate more dispersion. The distribution under either method of random assignment shows similar patterns. The estimated difference, $b-c$, is always positive, indicating that more recent increases in $Q$ are more important for equity issuance than the more distant increases in $Q$. However, 90 percent of the estimates fall below 0.175, while the equivalent estimate for the turnover group is 0.29 , greater than all 500 simulated estimates. This suggests that the larger impact on equity issues of the increases in $Q$ under the control of the current CEO is not entirely driven by the recency of these changes.

\section{Discussion: CEO-specific Q, other corporate decisions, and distress}

In most situations, equity issues follow strong past returns. We have identified a notable exception. When these past returns are not under the current CEO's control, there is less of a connection between equity issues and the firm's stock return history. While these findings are consistent with the attribution of past returns to the CEO, an alternative explanation is that CEO turnover marks a shift in strategy and the resulting change in fundamentals changes the pattern of equity issues. In other words, CEO identity still matters for raising capital, but rather than driving equity issues, the CEO is merely a marker for more fundamental changes in the nature of the firm that require investment and new capital.

\subsection{CEO-specific past returns and other corporate decisions}

\footnotetext{
${ }^{13}$ Using the equity issuance indicator as the dependent variable yields similar results.
} 
Both explanations lead naturally to the question of how the proceeds are used. Past returns are associated with increases in not only equity issues, but also debt issues, investment, and other assets. If the increased equity in response to past returns under the current CEO's control is connected to future investment opportunities, we should see the same returns having a disproportionate effect on other corporate decisions. Therefore, we examine the relation between CEO-specific past returns and other balance sheet changes as well as firm investment and profitability.

Other balance sheet changes are considered in Table 3. The first three pairs of columns show the assets side of the balance sheet: changes in Cash, WorkingCapital, and LongTermAssets. The next two pairs of columns show the liabilities side of the balance sheet, excluding external equity issues: changes in Debt and RetainedEarnings. This leaves some other long-term liabilities, including minority interests, and so on, which we define as a residual OtherLiabilities. We compute changes in these quarterly balance sheet measures and scale by total assets. We run the same specification as in equation (2), with these measures replacing net equity issues as the dependent variable. In each regression, we include the control variables as well as year-month and firm fixed effects. The adding up constraint requires that the equity issue be "used" either in reducing other liabilities or increasing assets. This test therefore helps answering the question of where on average the equity issues induced by CEO-specific returns go.

\section{[INSERT TABLE 3 HERE]}

The quick summary is that, as in past research, we find a strong connection between valuation levels and balance sheet growth. However, there is no special link when these returns are under the current CEO's control. Because of the balance sheet identity, the increase in equity that we found earlier must be offset by a corresponding increase in assets or a reduction in liabilities. However, none of the effects is individually strong, and the difference between recent changes in $Q$ and more distant changes in $Q$ largely does not vary significantly across the turnover group and the non-turnover group with randomly assigned turnover dates. 
Similarly, when we look at future profitability and investment (reported in the Internet Appendix Table A7), we see modest effects. Instead of equity issues or the balance sheet decomposition, we use CapitalExpenditure and EBITDA/A as dependent variables. CapitalExpenditure is defined as capital expenditures (Item 90) divided by assets. As before, valuation levels are strongly related to future investment and profitability, but the effect is not stronger when the changes in valuation are under the control of the current CEO. Our basic results could in principle come from a shift in fundamentals, with valuation creation under the current CEO’s control as an improved indicator of future firm investment opportunities. But, we do not see evidence of this in investment directly.

\subsection{CEO-specific past returns and restructuring}

Another possibility is that the investment opportunity is in restructuring, not expanding assets. To assess this alternative, we partition our sample in four ways according to turnover types. First, we separate firms based on whether the turnover is natural or forced. Second, we separate firms based on whether the new CEO is an internal candidate or an outside hire. Third, we group firms with no debt at the CEO turnover and firms with debt at the CEO turnover. ${ }^{14}$ Finally, we group firms with positive changes in $Q$ prior to the change in CEO and firms with negative changes in $Q$ prior to the change in CEO. The idea is to see whether our results are coming entirely from clear turnaround situations where the CEO was forced out after a period of poor performance or high financial distress. This is not the case.

We rerun the analysis in Table 2, regressing equity issues on the change in $Q$ under the current CEO’s tenure and the change in $Q$ prior to the current CEO's tenure. But, we perform an extra division of $Q$ by splitting the effects of the changes in $Q$ as well as the initial level of $Q$ according to the turnover type. Specifically, in Table 4, we run regressions of the following type on the sample of turnover firms:

\footnotetext{
${ }^{14}$ Approximately ten percent of the observations have no debt at the CEO turnover. Using different cutoffs to categorize firms into those with low debt at the CEO turnover and those with high debt at the CEO turnover produces similar results.
} 


$$
\begin{aligned}
\text { EquityIssuance }_{i t}= & a_{t}+\left(b_{1}+b_{2} N e w\right)\left(Q_{i, t-1}-Q_{i, C E O}\right)+\left(c_{1}+c_{2} N e w\right)\left(Q_{i, C E O}-Q_{i, t-13}\right) \\
& +\left(d_{1}+d_{2} N e w\right) Q_{i, t-13}+e N e w+f X_{i, t-1}+u_{i t}
\end{aligned}
$$

where New is equal to one if the turnover is forced (in the first regression); if the firm appoints an outsider CEO (in the second regression); if the firm is levered at turnover (in the third regression); and if the firm had a decrease in value at turnover (in the last regression). ${ }^{15}$

\section{[INSERT TABLE 4 HERE]}

We find little difference between the different types of turnover. The effect of past change in $Q$ is similar regardless of the nature of the turnover and the origin of the CEO, regardless of whether the firm has leverage or not, and regardless of whether the changes in $Q$ leading up to CEO transition are positive or negative. Our main test is whether the difference $b_{2}$ - $c_{2}$ is statistically positive: a positive and significant difference $b_{2}-c_{2}$ would indicate that our results are likely primarily driven by restructuring situations. None of the four estimates in Table 4 approaches statistical significance, with three negative and one positive coefficients. The results with an indicator variable for equity issues are similar. Therefore, our results are not simply coming from apparent turnaround situations.

This casts some doubt on the alternative explanation that our results are coming not from CEO identity, but from an underlying shift in strategy that breaks the link between equity issues and past performance.

\subsection{Discontinuity around CEO reference points}

Despite our best efforts, it is difficult to entirely rule out a neoclassical explanation where changes in valuation prior to the current CEO's tenure are less informative for the real benefits of raising equity capital. We can, however, rule in an important role for CEO reference points in equity issues with a discontinuity analysis. ${ }^{16}$ The reference point story makes two testable

\footnotetext{
${ }^{15}$ We have examined other measures, such as the stock return prior to the current CEO's tenure, the change in profitability, the change in assets, all with similar results.

${ }^{16}$ In a similar approach, Roberts and Sufi (2008) examine the discontinuous effects of covenant violations on corporate finance and investment.
} 
predictions. First, the specific price inherited by the new CEO is a clear reference point in the turnover sample. Second, a salient price prior to the arrival of the CEO is not.

To test the first prediction, we examine the pricing of follow-on or seasoned equity offerings for our sample firms, with data from Thomson Financial. We divide the sample of offerings into two groups. For each equity offering in a firm with a CEO turnover in the previous 36 months, we record the stock price of the firm at the end of the month prior to the CEO's appointment. For each equity offering in a firm with no CEO turnover in the previous 36 months, we randomly assign a turnover date as before, from the distribution of lags from the turnover sample, matched on industry and year-quarter. For each sample, we compute the ratio of the offering price to the stock price prior to a real or randomized turnover date. We then employ the non-parametric regression discontinuity approach of Hahn, Todd, and Van der Klaauw (2001) and Porter (2003). Using kernel-weighted locally linear regressions, we estimate the function relating the frequency of equity issues to the price ratios, and, more importantly, the implied discontinuity at the price ratio of one. ${ }^{17}$ For the non-turnover sample, we report the average frequency based on 500 different sets of simulated turnover dates.

The results are displayed in Figure 2. Panel A shows the distribution of 505 equity issues in firms with a CEO turnover at some point during the 36 months prior to the equity offering. Panel B shows the distribution of 1,090 equity issues where there was no CEO turnover in the 36-month period prior to the offering. ${ }^{18}$ As predicted, the stock price at the CEO's arrival is an important and discontinuous anchor for equity issuance in Panel A. There is an estimated discontinuous jump of 2.96 percent in the frequency of equity issues at the price ratio of one, significant at the one percent level. The simulated turnover dates in Panel B show no such pattern.

\footnotetext{
${ }^{17}$ We use the triangle kernel, with a bandwidth of 0.3 . Our results are robust to alternative bandwidths. Standard errors of the discontinuity estimates are derived using the formula from Porter (2003).

${ }^{18}$ The sample of seasoned equity offerings is small when compared to our full sample. This is consistent with Fama and French (2005), who find that seasoned equity offerings are rare among the sort of large firms that are in our ExecuComp sample.
} 


\section{[INSERT FIGURE 2 HERE]}

To test the second prediction, we examine adjacent follow-on offerings. The idea is that the most recent offering price is particularly salient in the decision to raise new equity. For each pair of adjacent offerings in the same firm, we compute the ratio of offering prices. We then split the sample as before into two groups: firms with no CEO turnover in between offerings, and firms with a CEO turnover in between offerings. As before, we employ a non-parametric regression discontinuity approach to estimate the function relating the frequency of equity issues to the price ratios, and the implied discontinuity at the price ratio of one.

\section{[INSERT FIGURE 3 HERE]}

Our results are shown in Figure 3. Panel A shows the distribution of 926 seasoned equity offerings where there was no CEO turnover since the last offering since 1990. Panel B shows the distribution of 383 seasoned equity offerings where a CEO turnover had occurred since the last offering since 1990. Here, we are expecting just the opposite. The prior offering price is only salient to the group with no turnover. Moreover, the no turnover group will be much more reluctant to issue equity at a lower price than in the previous offering. These results are stronger still, albeit in a small sample. As predicted, only 22.2 percent of the most recent offerings are priced below the offer price of the previous offering in Panel A. In contrast, after a CEO turnover in Panel B, 44.9 percent of the equity issues are offered below the price of the previous offering, which occurred under a different CEO. More importantly, when two adjacent equity issues are under the tenure of the same CEO, there is a discontinuous jump in the frequency of equity issues at the price ratio of one. The estimated jump discontinuity in Panel A is 7.22 percent, significant at the one percent level. This suggests that the CEO, as a rule of thumb, is reluctant to issue equity if the current price is below the last offer price under his control. No such jump pattern exists for two adjacent issues with a CEO turnover in between.

\section{Conclusions}


Equity issues follow periods of strong equity market performance. Typical interpretations are connected to $Q$ theory, asymmetric information, or opportunistic financing. In all three cases, the link is implicitly to firm investment opportunities, information about the firm, or investors' sentiment about the prospects of the firm. In contrast, we focus on the individual CEO presiding over these returns. With this in mind, we examine separately the effect of returns generated by the CEO and returns inherited by the CEO.

Our basic finding is that equity issues are much more sensitive to valuation levels and past returns when those returns are generated during the current CEO's tenure. A unit increase in $Q$ during the current CEO's tenure increases the probability of equity issue by almost twice as much as a unit increase prior to the arrival of the CEO. Even after controlling for the recency effect of the changes in $Q$, increases in $Q$ when under the control of the current CEO still increase the probability of an equity issue by 1.25 to 1.69 percentage points per quarter, approximately 30\% over the unconditional probability of an equity issue of 4.5 percent per quarter, more than when these changes are realized prior to the arrival of the CEO. Situations of natural turnover, where the board has selected what is typically an internal replacement for a retiring CEO, and forced turnover generate similar patterns.

This highlights the role of CEO identity in the capital raising process. The demand as well as the supply of equity may depend on the return history of the CEO, not the firm, due to the attribution of past performance to the individual CEO and not the firm more generally. Our results are unlikely to be driven by changes in capital or restructuring requirements around CEO turnover that are relatively independent of past returns. We find that the additional equity issuance is split between asset growth and reduction in liabilities and that our results are present in a variety of turnover settings: forced and natural turnover; insider and outsider; high debt and low; strong pre-turnover performance and weak. Moreover, the differential effect of the CEOspecific past returns persists even one year or more after turnover. Perhaps most convincingly, there is a discontinuous jump in the distribution of equity issues at the price inherited by the current CEO and no such jump at the salient level of the most recent past offering price, when 
this offering occurred prior to the current CEO's arrival. This casts some doubt on the endogeneity explanation, where it is investment or recapitalization following distress that drives equity issues.

A corollary is that a firm with poor stock market performance may be better able to raise new equity capital if its current CEO is replaced. When a CEO is removed involuntarily, the firm's historical value creation or destruction becomes less relevant for future equity issues. An equity issue is equally probable whether these old returns are high or low. This has some resonance at the outset of the 2007-2008 credit crisis. Banks needed significant equity capital infusions to offset mortgage losses. This was a challenging proposition in the context of very poor recent stock performance. Partly in response, most replaced their CEOs, opening the door to new funds. 


\section{References}

Baker, Malcolm, and Jeffrey Wurgler, 2000, The equity share in new issues and aggregate stock returns, Journal of Finance 55, 2219-2257.

Baker, Malcolm, and Jeffrey Wurgler, 2002, Market timing and capital structure, Journal of Finance 57, 1-32.

Baker, Malcolm, Xin Pan, and Jeffrey Wurgler, 2012, The effect of reference point prices on mergers and acquisitions, Journal of Financial Economics 106, 49-71.

Bebchuk, Lucian, Martijn Cremers, and Urs Peyer, 2011, The CEO pay slice, Journal of Financial Economics 102, 199-221.

Berk, Jonathan, and Richard Green, 2005, Mutual fund flows and performance in rational markets, Journal of Political Economy 112, 1269-1295.

Bertrand, Marianne, and Antoinette Schoar, 2003, Managing with style: The effect of managers on firm policies, Quarterly Journal of Economics 118, 1169-1208.

The Boston Globe, 2006, Global heavyweights, The Boston Globe (November 26, 2006).

Chevalier, Judith, and Glenn Ellison, 1997, Risk taking by mutual funds as a response to incentives, Journal of Political Economy 105, 1167-1200.

Connelly, Eileen, and Shaila Dani, 2009, Gorman will succeed Mack as CEO of Morgan Stanley, Associate Press Newswires (September 10, 2009).

Fama, Eugene F., and Kenneth R. French, 2005, Financing decisions: Who issues stock? Journal of Financial Economics 76, 549-582.

Frazzini, Andrea, and Owen Lamont, 2008, Dumb money: mutual fund flows and the crosssection of stock returns, Journal of Financial Economics 88, 299-322.

Gelsi, Steve, 2009, O'Reilly to retire as Chevron CEO, Watson taking reins, MarketWatch (October 1, 2009).

Graham, John, and Krishna Narasimhan, 2005, Corporate survival and managerial experiences during the great depression, Duke University Working Paper.

Hahn, Jinyong, Petra Todd, and Wilbert Van der Klaauw, 2001, Identification and estimation of treatment effects with a regression-discontinuity design, Econometrica 69, 201-209.

Huang, Rongbing, and Jay R. Ritter, 2009, Testing theories of capital structure and estimating the speed of adjustment, Journal of Financial and Quantitative Analysis 44, 237-271. 
Jin, Li, and Anna Scherbina, 2011, Inheriting losers, Review of Financial Studies 24, 786-820.

Jones, Edward, and Victor Harris, 1967, The attribution of attitudes, Journal of Experimental Social Psychology 3, 1-24.

Kahneman, Daniel, and Amos Tversky, 1979, Prospect theory: An analysis of decision under risk, Econometrica 47, 263-291.

Kaplan, Steven, Mark Klebanov, and Morten Sorensen, 2012, Which CEO characteristics and abilities matter? Journal of Finance 67, 973-1007. \#

Khurana, Rakesh, 2002, Searching for a corporate savior: The irrational quest for charismatic CEOs (Princeton, N.J.: Princeton University Press).

Korajczyk, Robert, Deborah Lucas, and Robert McDonald, 1992, Equity issues with timevarying asymmetric information, Journal of Financial and Quantitative Analysis 27, 397-417.

Lauria, Peter, 2006, T’Iger shark; after one year, Disney CEO OK, New York Post (October 29, 2006).

Ljungqvist, Alexander, and William J. Wilhelm Jr., 2005, Does prospect theory explain IPO market behavior? Journal of Finance 60, 1759-1790.

Loughran, Tim, and Jay R. Ritter, 1995, The new issues puzzle, Journal of Finance 50, $23-51$.

Loughran, Tim, and Jay R. Ritter, 2002, Why don’t issuers get upset about leaving money on the table in IPOs? Review of Financial Studies 15, 413-443.

Lucas, Deborah, and Robert McDonald, 1990, Equity issues and stock price dynamics, Journal of Finance 45, 1019-1043.

Malmendier, Ulrike, and Geoff Tate, 2009, Superstar CEOs, Quarterly Journal of Economics 124, 1593-1638.

Murphy, Kevin, and Jared Zimmerman, 1993, Financial Performance Surrounding CEO Turnover, Journal of Accounting and Economics 16, 273-315.

Odean, Terence, 1998, Are investors reluctant to realize their losses? Journal of Finance 53, 1775-1798.

Porter, Jack, 2003, Estimation in the regression discontinuity model, University of Wisconsin Working Paper. 
Ritter, Jay R., 1991, The long-run performance of initial public offerings, Journal of Finance 46, 3-27.

Roberts, Michael, and Amir Sufi, 2009, Control rights and capital structure: An empirical investigation, Journal of Finance 64, 1657-1695.

Ross, Lee, 1977, The intuitive psychologist and his shortcomings: Distortions in the attribution process, Advances in Experimental Social Psychology 10, 173-220.

Shefrin, Hersh, and Meir Statman, 1985, The disposition to sell winners too early and ride losers too long: Theory and evidence, Journal of Finance 40, 777-790.

Sirri, Erik, and Peter Tufano, 1998, Costly search and mutual fund flows, Journal of Finance 53, 1589-1622.

Stigler, George, 1964, Public regulation of the securities markets, Journal of Business 37, 117142.

Terhune, Chad, 2005, Isdell could lose Coke’s Cola crown, The Wall Street Journal (December 7, 2005).

Thakor, Anjan V., and Toni Whited, 2011, Shareholder-manager disagreement and corporate investment, Review of Finance 15, 277-300.

Tobin, James. 1969, A general equilibrium approach to monetary theory, Journal of Money, Credit, and Banking 1, 15-29.

von Furstenberg, George M., 1977, Corporate investment: does market valuation matter in the aggregate? Brookings Papers on Economic Activity 2, 347-397.

Xuan, Yuhai, 2009, Empire-building or bridge-building? Evidence from new CEOs' internal capital allocation decisions, Review of Financial Studies 22, 4919-4948.

Yakabuski, Konrad, 2004, Hit the breaks...full speed ahead, The Global and Mail (August 27, 2004). 
Figure 1. CEO-Specific $Q$ and Equity Issuance. This figure shows the distribution of the difference, $b-c$, from estimating the following regression for the non-turnover group:

$$
\text { EquityIssuance }_{i t}=a_{t}+b\left(Q_{i, t-1}-Q_{i, C E O}\right)+c\left(Q_{i, C E O}-Q_{i, t-13}\right)+d Q_{i, t-13}+e X_{i, t-1}+u_{i t}
$$

We use net equity issuance $(e / A)$ as the dependent variable and include controls for lagged profitability, size, and leverage. We include year-month and firm fixed effects. The turnover date for the non-turnover group is chosen randomly from the distribution of lags from the turnover sample. The distribution of the estimated difference, $b-c$, is generated from 500 simulations. The equivalent estimate of $b-c$ for the turnover group alone is 0.29 .

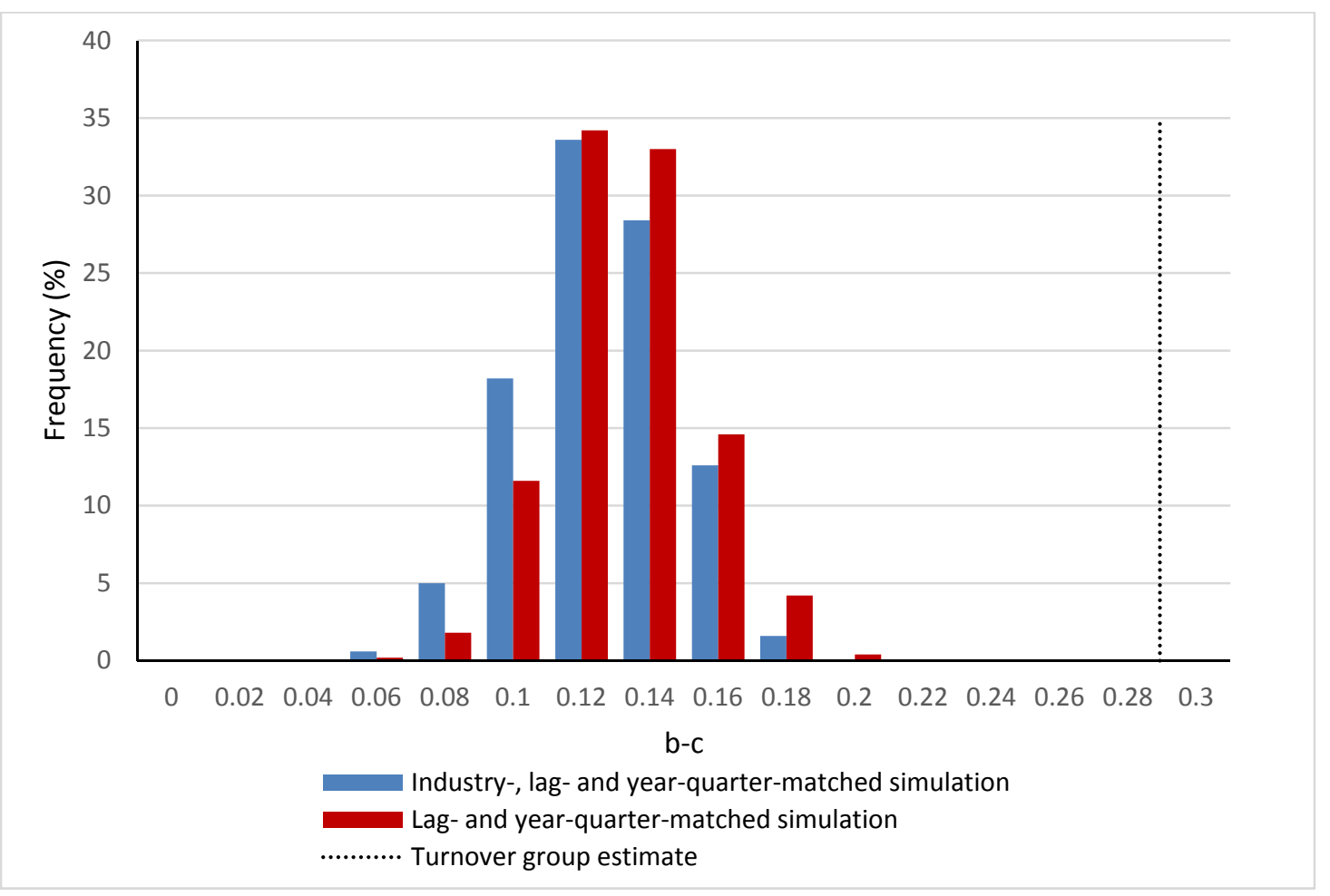


Figure 2. Price of seasoned equity offering and stock price at CEO turnover. This figure shows the nonparametric estimate for the function relating the frequency of equity issues to the ratio of the offer price to the stock price at CEO turnover as well as the implied discontinuity at the ratio of one. Each dot in the figure represents the percentage of seasoned equity offerings with a ratio of the offer price to the stock price at CEO turnover that falls in the corresponding bin on the x-axis. Panel A: CEO turnover occurred at some point during the 36 months prior to the equity offering. Estimated discontinuity $=2.96 \% ; p$-value $=0.00$. Panel B: No CEO turnover occurred in the 36-month period prior to the equity offering. Stock prices at turnover use randomly assigned turnover dates from the distribution of lags from the turnover sample. We report the average frequency based on 500 sets of simulated dates. Estimated discontinuity $=1.52 \% ; p$-value $=0.21$.

Panel A. CEO turnover in the prior 36 months

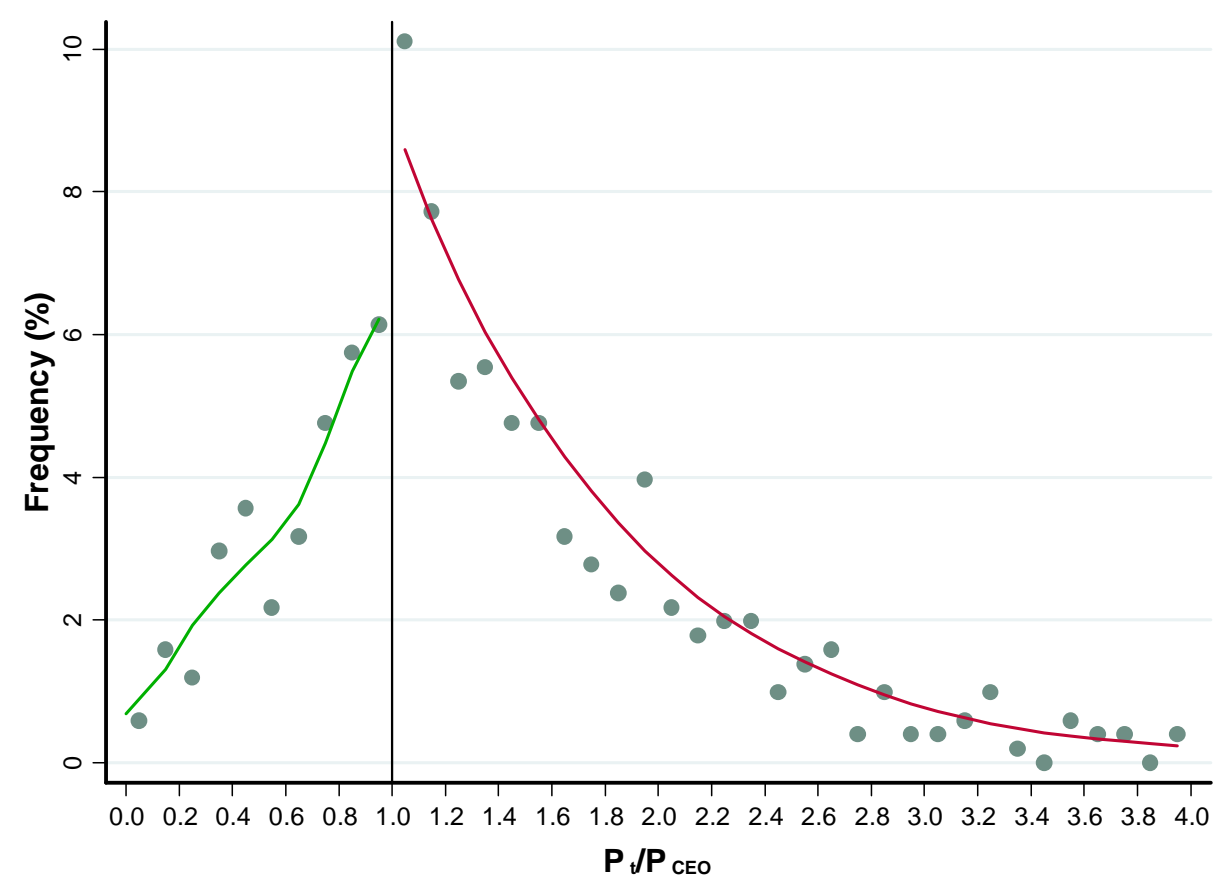

Panel B. No CEO turnover in the prior 36 months

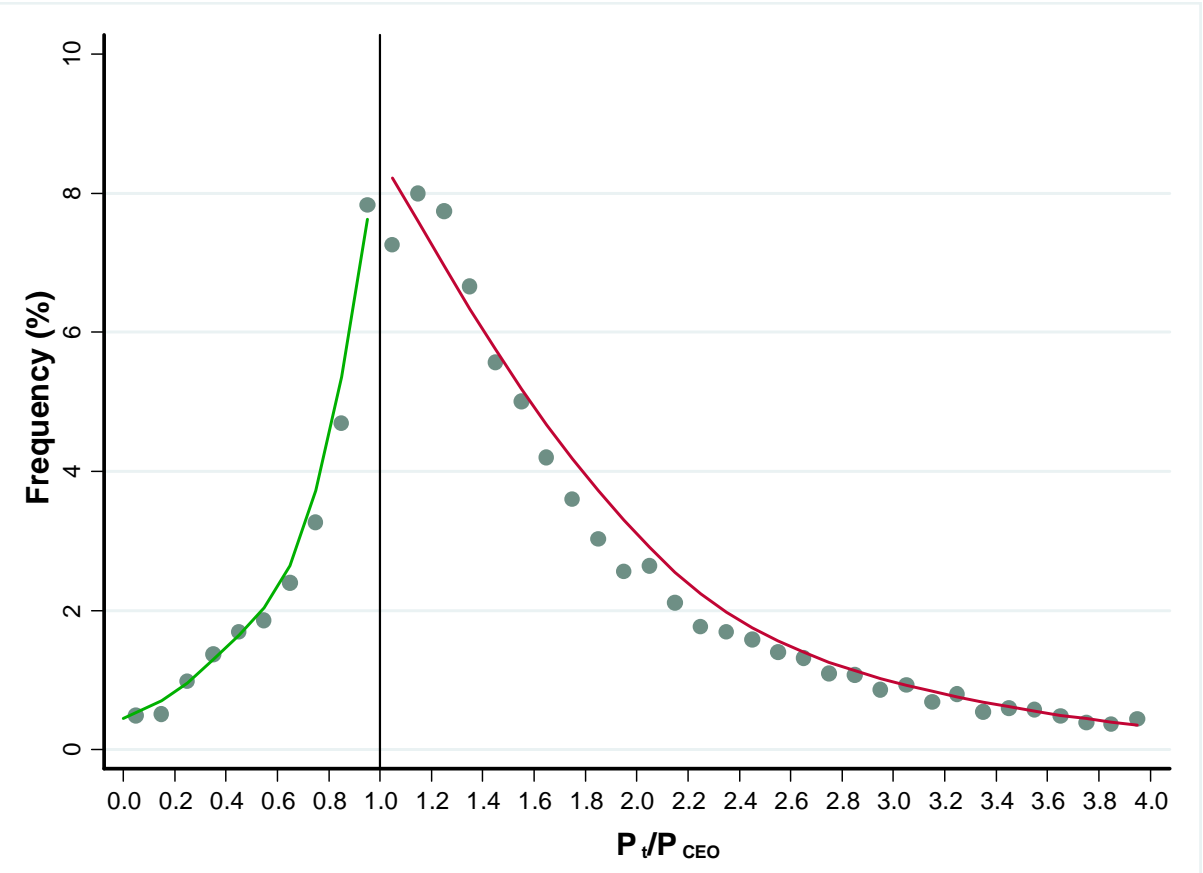


Figure 3. Price ratios of adjacent seasoned equity offerings. This figure shows the nonparametric estimate for the function relating the frequency of equity issues to the price ratio of two adjacent offerings as well as the implied discontinuity at the price ratio of one. Each dot in the figure represents the percentage of seasoned equity offerings with a price ratio of two adjacent offerings that falls in the corresponding bin on the x-axis. Panel A: No CEO turnover between two adjacent equity issues. Estimated discontinuity $=7.22 \% ; p$-value $=0.01$. Panel $\mathrm{B}$ : CEO turnover between two adjacent equity issues. Estimated discontinuity $=1.28 \%$; $p$-value $=$ 0.26 .

Panel A. No CEO turnover between adjacent seasoned equity offerings

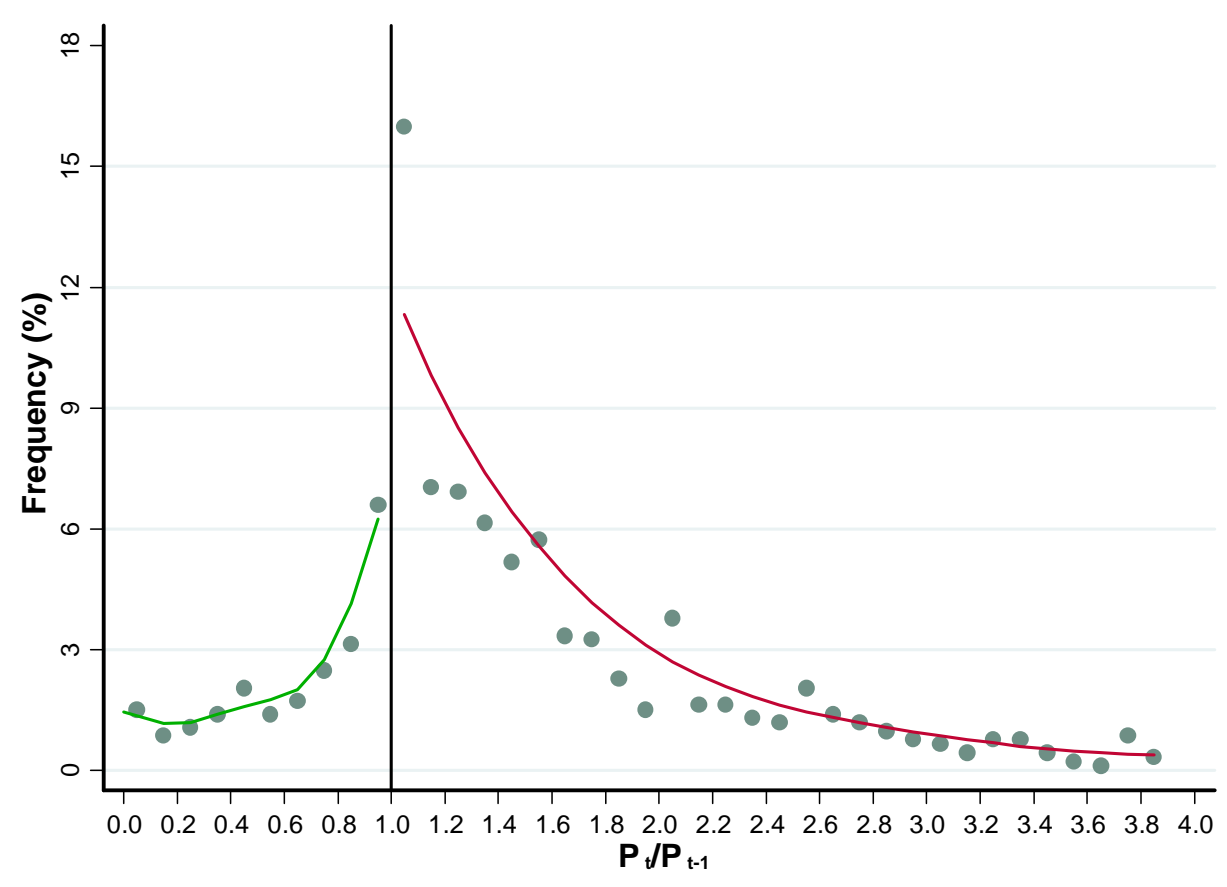

Panel B. CEO turnover between adjacent seasoned equity offerings

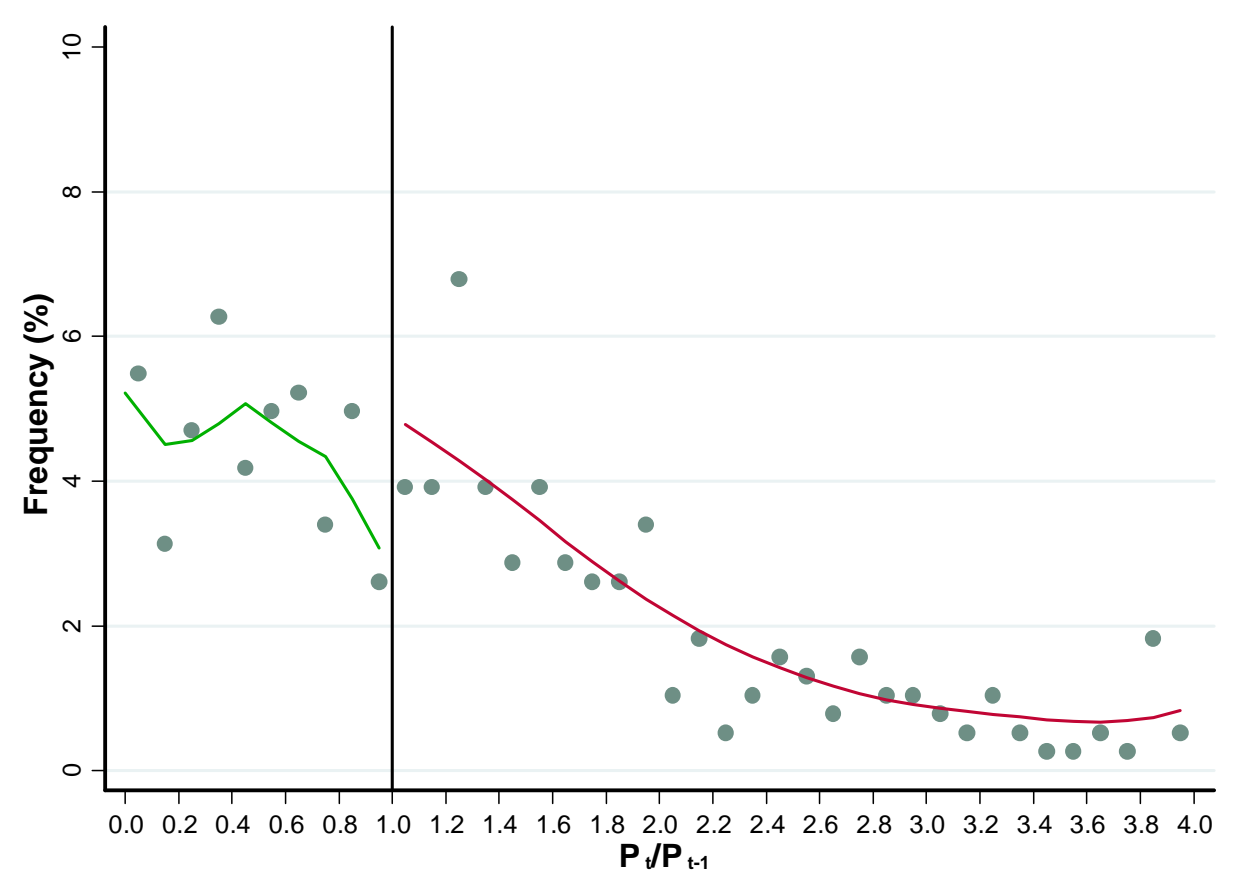




\section{Table 1}

Summary statistics

This table summarizes quarterly equity issuance and other quarterly financial data for the sample of S\&P 1500 firms in ExecuComp from 1990 to 2011. Cash is cash and short-term investments (Compustat Industrial Quarterly Item 36). WorkingCapital is current assets (Item 40) minus current liabilities (Item 49) plus debt in current liabilities (Item 45) minus cash. LongTermAssets is calculated as assets minus current assets. Debt is defined as the sum of long-term debt (Item 51) and debt in current liabilities. ExternalEquity is defined as book equity minus balance sheet RetainedEarnings (Item 58). Book equity is defined as total assets less total liabilities (Item 54) and preferred stock (Item 55) plus deferred taxes (Item 52 ). The net equity issuer dummy ( $/$ /A $>5 \%$ ) takes the value one if net equity issuance $(\mathrm{e} / \mathrm{A})$ equals or exceeds five percent and zero otherwise. OtherLiabilities is defined as the difference between assets and the sum of non-debt current liabilities, debt and book equity. $Q$ is defined as the book value of assets A (Item 44) plus the market value of equity (end-of-quarter price, Item 14, times end-of-quarter shares outstanding, Item 61) minus book equity all over assets. Leverage $(D / A)$ is defined as debt divided by assets. Profitability $(E B I T D A / A)$ is defined as operating income before depreciation (Item 21) divided by assets. "No Turnover Group" indicates that there was no CEO turnover in the 36month period prior to the quarter. "Turnover Group" indicates that a CEO turnover occurred at some point during the 36 months prior to the quarter. All variables are winsorized at the $1^{\text {st }}$ and $99^{\text {th }}$ percentiles.

\begin{tabular}{|c|c|c|c|c|c|c|}
\hline & \multicolumn{3}{|c|}{ No Turnover } & \multicolumn{3}{|c|}{ Turnover } \\
\hline \multicolumn{7}{|l|}{ Changes from last quarter in } \\
\hline Cash: $\Delta$ Cash/A $(\%)$ & 57,825 & 0.25 & 4.26 & 29,663 & 0.15 & 4.41 \\
\hline Working Capital: ( $\Delta$ OtherCA- $\Delta \mathrm{NDCL}) / \mathrm{A}_{\mathrm{t}}(\%)$ & 57,825 & 0.21 & 3.42 & 29,663 & 0.09 & 3.62 \\
\hline Long-term assets: $\Delta$ LTAsset $/ A_{t}(\%)$ & 57,825 & 1.17 & 4.50 & 29,663 & 0.68 & 4.60 \\
\hline External equity: e/At $(\%)$ & 57,825 & 0.57 & 3.44 & 29,663 & 0.44 & 3.46 \\
\hline External equity: e/At $>5 \%(x 100)$ & 57,825 & 4.55 & 20.84 & 29,663 & 4.35 & 20.40 \\
\hline Retained earnings: $\Delta R E / A_{t}(\%)$ & 57,825 & 0.59 & 3.55 & 29,663 & 0.17 & 4.06 \\
\hline Other liabilities: $\Delta$ OtherL/ $\mathrm{A}_{\mathrm{t}}(\%)$ & 57,825 & 0.13 & 1.28 & 29,663 & 0.14 & 1.41 \\
\hline Assets: $A_{t}$ & 57,825 & $4,607.87$ & $10,314.33$ & 29,663 & $5,327.43$ & $10,962.26$ \\
\hline Leverage: $\mathrm{D} / \mathrm{A}_{\mathrm{t}}(\%)$ & 57,825 & 21.41 & 17.36 & 29,663 & 22.26 & 17.79 \\
\hline
\end{tabular}


Table 2

CEO-specific $Q$ and equity issuance

This table reports results of the following regression:

$$
\text { EquityIssuance }_{i t}=a_{t}+\left(b_{1}+b_{2} \text { Turn }\right)\left(Q_{i, t-1}-Q_{i, C E O}\right)+\left(c_{1}+c_{2} \text { Turn }\right)\left(Q_{i, C E O}-Q_{i, t-13}\right)+\left(d_{1}+d_{2} \text { Turn }\right) Q_{i, t-13}+e \text { Turn }+f X_{i, t-1}+u_{i t} .
$$

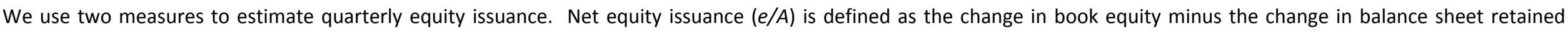

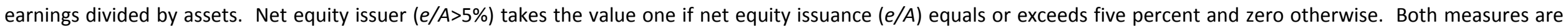

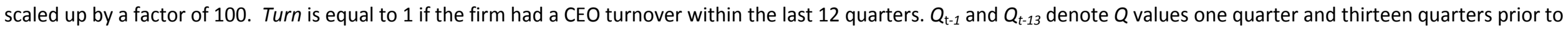

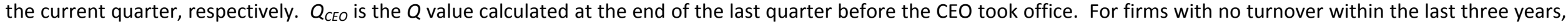

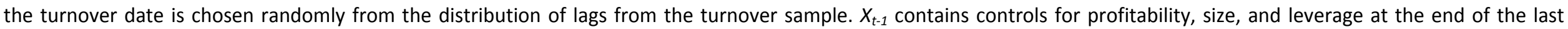
quarter. P-values based on robust standard errors clustered by firm are reported in brackets.

\begin{tabular}{|c|c|c|c|c|c|c|c|c|c|c|c|c|}
\hline & \multicolumn{6}{|c|}{ Equity Issues: $e / A$} & \multicolumn{6}{|c|}{ Equity Issues: $e / A>5 \%$} \\
\hline & Coef & [p-val] & Coef & [p-val] & Coef & [p-val] & Coef & [p-val] & Coef & [p-val] & Coef & [p-val] \\
\hline \multicolumn{13}{|l|}{ Turnover Group: } \\
\hline $\mathrm{Q}_{\mathrm{t}-1}-\mathrm{Q}_{\mathrm{CEO}}$ & 0.64 & {$[<0.01]$} & 0.74 & {$[<0.01]$} & 0.74 & {$[<0.01]$} & 4.04 & {$[<0.01]$} & 4.56 & {$[<0.01]$} & 4.18 & {$[<0.01]$} \\
\hline $\mathrm{Q}_{\mathrm{CEO}}-\mathrm{Q}_{\mathrm{t}-13}$ & 0.24 & {$[<0.01]$} & 0.45 & {$[<0.01]$} & 0.45 & {$[<0.01]$} & 1.97 & {$[<0.01]$} & 2.93 & {$[<0.01]$} & 2.53 & {$[<0.01]$} \\
\hline $\mathrm{Q}_{\mathrm{t}-13}$ & 0.31 & {$[<0.01]$} & 0.46 & {$[<0.01]$} & 0.55 & {$[<0.01]$} & 2.40 & {$[<0.01]$} & 3.18 & {$[<0.01]$} & 3.07 & {$[<0.01]$} \\
\hline \multicolumn{13}{|l|}{ Non-Turnover Group: } \\
\hline $\mathrm{Q}_{\mathrm{t}-1}-\mathrm{Q}_{\mathrm{CEO}}$ & 0.57 & {$[<0.01]$} & 0.72 & {$[<0.01]$} & 0.70 & {$[<0.01]$} & 2.87 & {$[<0.01]$} & 3.62 & {$[<0.01]$} & 3.46 & {$[<0.01]$} \\
\hline$Q_{C E O}-Q_{t-13}$ & 0.46 & {$[<0.01]$} & 0.61 & {$[<0.01]$} & 0.60 & {$[<0.01]$} & 2.49 & {$[<0.01]$} & 3.24 & {$[<0.01]$} & 3.11 & {$[<0.01]$} \\
\hline $\mathrm{Q}_{\mathrm{t}-13}$ & 0.40 & {$[<0.01]$} & 0.52 & {$[<0.01]$} & 0.58 & {$[<0.01]$} & 2.18 & {$[<0.01]$} & 2.85 & {$[<0.01]$} & 2.92 & {$[<0.01]$} \\
\hline$b_{2}-c_{2}$ & 0.29 & {$[<0.01]$} & 0.18 & {$[0.01]$} & 0.19 & {$[0.01]$} & 1.69 & {$[<0.01]$} & 1.25 & {$[<0.01]$} & 1.30 & {$[<0.01]$} \\
\hline Turn & 0.08 & {$[0.49]$} & 0.01 & {$[0.94]$} & 0.00 & {$[0.98]$} & -0.35 & {$[0.51]$} & -0.67 & {$[0.15]$} & -0.14 & {$[0.73]$} \\
\hline Profitability: EBITDA/A $(\%)$ & & & -0.16 & {$[<0.01]$} & -0.02 & {$[0.07]$} & & & -0.75 & {$[<0.01]$} & -0.07 & {$[0.31]$} \\
\hline Assets: $\ln \left(A_{t}\right)$ & & & -0.22 & {$[<0.01]$} & -0.56 & {$[<0.01]$} & & & -0.82 & {$[<0.01]$} & -2.30 & {$[<0.01]$} \\
\hline Leverage: $\mathrm{D} / \mathrm{A}_{\mathrm{t}}(\%)$ & & & 0.02 & {$[<0.01]$} & 0.03 & {$[<0.01]$} & & & 0.09 & {$[<0.01]$} & 0.11 & {$[<0.01]$} \\
\hline \multicolumn{13}{|l|}{ Fixed effects } \\
\hline Year-Month & & Yes & & Yes & & Yes & & Yes & & Yes & & Yes \\
\hline Firm & & No & & No & & Yes & & No & & No & & Yes \\
\hline $\mathrm{N}$ & & 85,061 & & 85,061 & & 85,061 & & 85,061 & & 85,061 & & 85,061 \\
\hline $\mathrm{R}^{2}$ & & 0.04 & & 0.08 & & 0.16 & & 0.04 & & 0.05 & & 0.12 \\
\hline
\end{tabular}


Table 3

CEO-specific $Q$ and other balance sheet changes

This table estimates the following regression:

$\Delta$ OtherBalanceSheetItems $_{i t}=a_{t}+\left(b_{1}+b_{2}\right.$ Turn $)\left(Q_{i, t-1}-Q_{i, C E O}\right)+\left(c_{1}+c_{2}\right.$ Turn $)\left(Q_{i, C E O}-Q_{i, t-13}\right)+\left(d_{1}+d_{2} T_{u r n}\right) Q_{i, t-13}+e T u r n+f X_{i, t-1}+u_{i t}$.

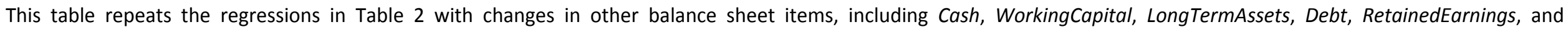
OtherLiabilities. All dependent variables are scaled up by a factor of 100 . P-values based on robust standard errors clustered by firm are reported in brackets.

\begin{tabular}{|c|c|c|c|c|c|c|c|c|c|c|c|c|}
\hline & \multicolumn{2}{|c|}{ Change in Cash } & \multicolumn{2}{|c|}{$\begin{array}{c}\text { Change in Working } \\
\text { Capital }\end{array}$} & \multicolumn{2}{|c|}{$\begin{array}{c}\text { Change in Long } \\
\text { Term Assets }\end{array}$} & \multicolumn{2}{|c|}{ Change in Debt } & \multicolumn{2}{|c|}{$\begin{array}{c}\text { Change in Retained } \\
\text { Earnings }\end{array}$} & \multicolumn{2}{|c|}{$\begin{array}{c}\text { Change in Other } \\
\text { Liabilities }\end{array}$} \\
\hline & Coef & [p-val] & Coef & [p-val] & Coef & [p-val] & Coef & [p-val] & Coef & [p-val] & Coef & [p-val] \\
\hline \multicolumn{13}{|l|}{ Turnover Group: } \\
\hline $\mathrm{Q}_{\mathrm{t}-1}-\mathrm{Q}_{\mathrm{CEO}}$ & 0.45 & {$[<0.01]$} & 0.26 & {$[<0.01]$} & 0.56 & {$[<0.01]$} & 0.11 & {$[0.01]$} & 0.38 & {$[<0.01]$} & -0.01 & [0.34] \\
\hline $\mathrm{Q}_{\mathrm{CEO}}-\mathrm{Q}_{\mathrm{t}-13}$ & 0.17 & {$[<0.01]$} & 0.23 & {$[<0.01]$} & 0.65 & {$[<0.01]$} & 0.17 & {$[<0.01]$} & 0.37 & {$[<0.01]$} & 0.01 & {$[0.42]$} \\
\hline $\mathrm{Q}_{\mathrm{t}-13}$ & 0.20 & {$[<0.01]$} & 0.23 & {$[<0.01]$} & 0.64 & {$[<0.01]$} & 0.20 & {$[<0.01]$} & 0.29 & {$[<0.01]$} & 0.01 & {$[0.43]$} \\
\hline \multicolumn{13}{|l|}{ Non-Turnover Group: } \\
\hline $\mathrm{Q}_{\mathrm{t}-1}-\mathrm{Q}_{\mathrm{CEO}}$ & 0.48 & {$[<0.01]$} & 0.23 & {$[<0.01]$} & 0.47 & {$[<0.01]$} & 0.05 & [0.13] & 0.34 & {$[<0.01]$} & 0.01 & {$[0.30]$} \\
\hline $\mathrm{Q}_{\mathrm{CEO}}-\mathrm{Q}_{\mathrm{t}-13}$ & 0.28 & {$[<0.01]$} & 0.18 & {$[<0.01]$} & 0.59 & {$[<0.01]$} & 0.11 & {$[<0.01]$} & 0.27 & {$[<0.01]$} & 0.01 & [0.12] \\
\hline $\mathrm{Q}_{\mathrm{t}-13}$ & 0.32 & {$[<0.01]$} & 0.17 & {$[<0.01]$} & 0.55 & {$[<0.01]$} & 0.12 & {$[<0.01]$} & 0.27 & {$[<0.01]$} & 0.01 & {$[0.42]$} \\
\hline $\mathrm{b}_{2}-\mathrm{c}_{2}$ & 0.08 & {$[0.24]$} & -0.02 & {$[0.64]$} & 0.03 & {$[0.76]$} & 0.00 & [0.93] & -0.06 & {$[0.56]$} & -0.02 & {$[0.27]$} \\
\hline Turn & 0.20 & {$[0.01]$} & -0.17 & {$[<0.01]$} & -0.45 & {$[<0.01]$} & -0.32 & {$[<0.01]$} & -0.18 & {$[0.04]$} & -0.01 & [0.69] \\
\hline Profitability: EBITDA/A $(\%)$ & 0.16 & {$[<0.01]$} & 0.01 & {$[0.61]$} & 0.17 & {$[<0.01]$} & -0.04 & {$[0.02]$} & 0.42 & {$[<0.01]$} & 0.00 & {$[0.28]$} \\
\hline Assets: $\ln \left(A_{t}\right)$ & -0.34 & {$[<0.01]$} & -0.12 & {$[<0.01]$} & -0.43 & {$[<0.01]$} & -0.24 & {$[<0.01]$} & -0.05 & {$[0.33]$} & -0.01 & {$[0.48]$} \\
\hline Leverage: $D / A_{t}(\%)$ & 0.00 & {$[0.26]$} & -0.02 & {$[<0.01]$} & -0.03 & {$[<0.01]$} & -0.07 & {$[<0.01]$} & -0.01 & {$[<0.01]$} & 0.00 & {$[<0.01]$} \\
\hline \multicolumn{13}{|l|}{ Fixed effects } \\
\hline Year-Month & & Yes & & Yes & & Yes & & Yes & & Yes & & Yes \\
\hline Firm & & Yes & & Yes & & Yes & & Yes & & Yes & & Yes \\
\hline $\mathrm{N}$ & & 85,061 & & 85,061 & & 85,061 & & 85,061 & & 85,061 & & 85,061 \\
\hline $\mathrm{R}^{2}$ & & 0.06 & & 0.07 & & 0.11 & & 0.07 & & 0.34 & & 0.05 \\
\hline
\end{tabular}




\section{Table 4}

CEO-specific $Q$ and equity issuance: turnover types

This table estimates the following regression:

$$
\text { EquityIssuance }_{i t}=a_{t}+\left(b_{1}+b_{2} N e w\right)\left(Q_{i, t-1}-Q_{i, C E O}\right)+\left(c_{1}+c_{2} N e w\right)\left(Q_{i, C E O}-Q_{i, t-13}\right)+\left(d_{1}+d_{2} N e w\right) Q_{i, t-13}+e N e w+f X_{i, t-1}+u_{i t} \text {. }
$$

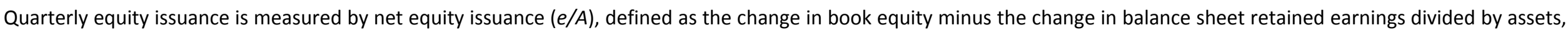

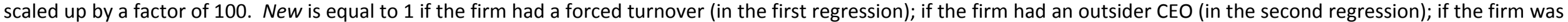

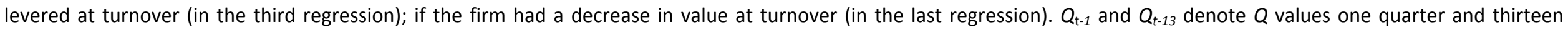

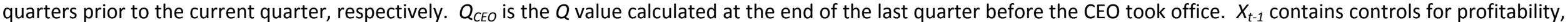

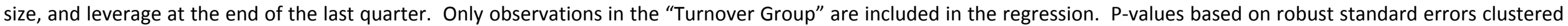
by firm are reported in brackets.

\begin{tabular}{|c|c|c|c|c|c|c|c|c|}
\hline & \multicolumn{2}{|c|}{$\begin{array}{l}\text { Natural versus } \\
\text { Forced }\end{array}$} & \multicolumn{2}{|c|}{$\begin{array}{l}\text { Insider versus } \\
\text { Outsider }\end{array}$} & \multicolumn{2}{|c|}{$\begin{array}{c}\text { No Debt versus With } \\
\text { Debt }\end{array}$} & \multicolumn{2}{|c|}{$\begin{array}{c}\mathrm{Q}_{\mathrm{CEO}}>\mathrm{Q}_{\mathrm{t}-13} \text { versus } \\
\mathrm{Q}_{\mathrm{CEO}}<\mathrm{Q}_{\mathrm{t}-13}\end{array}$} \\
\hline & Coef & [p-val] & Coef & [p-val] & Coef & [p-val] & Coef & [p-val] \\
\hline $\mathrm{Q}_{\mathrm{t}-1}-\mathrm{Q}_{\mathrm{CEO}}$ & 0.61 & {$[<0.01]$} & 0.59 & {$[<0.01]$} & 0.78 & {$[<0.01]$} & 0.65 & {$[<0.01]$} \\
\hline $\mathrm{Q}_{\mathrm{CEO}}-\mathrm{Q}_{\mathrm{t}-13}$ & 0.34 & {$[<0.01]$} & 0.36 & {$[<0.01]$} & 0.57 & {$[<0.01]$} & 0.33 & {$[0.01]$} \\
\hline $\mathrm{Q}_{\mathrm{t}-13}$ & 0.41 & {$[<0.01]$} & 0.40 & {$[<0.01]$} & 0.64 & {$[<0.01]$} & 0.50 & {$[<0.01]$} \\
\hline \multicolumn{9}{|c|}{ Forced/External/High Distress Group: } \\
\hline $\mathrm{Q}_{\mathrm{t}-1}-\mathrm{Q}_{\mathrm{CEO}}$ & 0.97 & {$[<0.01]$} & 1.01 & {$[<0.01]$} & 0.69 & {$[<0.01]$} & 0.79 & {$[<0.01]$} \\
\hline $\mathrm{Q}_{\mathrm{CEO}}-\mathrm{Q}_{\mathrm{t}-13}$ & 0.65 & {$[<0.01]$} & 0.63 & {$[<0.01]$} & 0.37 & {$[<0.01]$} & 0.48 & {$[<0.01]$} \\
\hline $\mathrm{Q}_{\mathrm{t}-13}$ & 0.70 & {$[<0.01]$} & 0.71 & {$[<0.01]$} & 0.43 & {$[<0.01]$} & 0.52 & {$[<0.01]$} \\
\hline $\mathrm{b}_{2}-\mathrm{c}_{2}$ & 0.05 & {$[0.77]$} & 0.15 & {$[0.19]$} & 0.11 & {$[0.64]$} & -0.01 & {$[0.95]$} \\
\hline New & -0.67 & {$[<0.01]$} & -0.54 & {$[0.01]$} & 0.49 & {$[0.14]$} & 0.08 & [0.49] \\
\hline Profitability: EBITDA/At $(\%)$ & -0.01 & {$[0.42]$} & -0.01 & {$[0.49]$} & -0.01 & {$[0.48]$} & -0.01 & {$[0.44]$} \\
\hline Assets: $\ln \left(A_{t}\right)$ & -0.67 & {$[<0.01]$} & -0.67 & {$[<0.01]$} & -0.68 & {$[<0.01]$} & -0.67 & {$[<0.01]$} \\
\hline Leverage: $\mathrm{D} / \mathrm{A}_{\mathrm{t}}(\%)$ & 0.04 & {$[<0.01]$} & 0.04 & {$[<0.01]$} & 0.04 & {$[<0.01]$} & 0.04 & {$[<0.01]$} \\
\hline $\mathrm{N}$ & & 29,552 & & 29,552 & & 29,552 & & 29,552 \\
\hline$R^{2}$ & & 0.22 & & 0.22 & & 0.22 & & 0.22 \\
\hline
\end{tabular}

